time or another. Presumably, the detergent is not always in sufficient quantity or concentration to "degrease" water birds, and perhaps most of those which do suffer somewhat are able to fly to clear waters, and can thus recover. An incredible amount of detergent foam blankets Wascana Creek for a considerable distance below the sewage lagoons, so it is feasible birds may suffer ill effects in the creek (for miles of its length) as well as in the lagoons. The total biological effect of this quantity of waste detergent flowing into our local streams may be more deleterious than we imagine. There have been newspaper accounts of recently developed chemicals which can be added at sewage treatment plants to alter detergents so that they can be broken down by bacteria (as is the case for ordinary soaps) and thus rendered harmless. We should perhaps bring this discovery to the attention of authorities concerned with waste disposal problems.

\section{RECORDS OF THE LAZULI BUNTING AND YELLOW-BREASTED CHAT}

\author{
by Dianne Fahselt, Regina
}

On Saturday, June 1, 1963, while on a weekend camping expedition with the Regina Natural History Society at Estevan, Sharon Haggerty and I identified a male Lazuli Bunting in the camping area near Roche Percee. Mrs. Mayot of Moose Jaw also saw the bird. - With George Ledingham in the Missouri Coteau near Claybank on July 6 another male Lazuli Bunting and possibly also a female were sighted. Since two male Lazuli Buntings were seen in approximately the same area in 1962 by a party on July 20 (Getting to know our less common birds, by M. Belcher and M. Rever, Blue Jay 20: 146-150), it is likely that these birds nest regularly in this part of the 'Missouri Coteau. E. M. Callin's 1.960 record of a Lazuli Burting at Font San (Blue Jay 18: 120) emphasizes how rare the bird is in that area. Other reports and nest records of Lazuli Buntings may be found through reference to the Blue Jay Index.

In the camp grounds near Roche Percee, Sunday, June 2, 1963, Sharon
Haggerty and I observed a Yellowbreasted Chat for some time as it flew from the top of one bush to the next, often "snapping" its tail in flight. Later we were not able to show the bird to Connie Pratt and Sylvia 'Harrison but they heard the song. Ross Lein of Estevan regards both the Yellow-breasted Chat and the Lazuli Bunting as possibly regular (but not common) nesting species in the Estevan area.

On July 1, I saw a Chat on two occasions along the South Saskatchewan River. At the old Empress ferry on July 12, my brother, Norman, and I sighted a Yellow-breasted Chat and George Ledingham heard it. The next morning, July 13, George Ledingham and I saw another chat along the river bank east of Cabri. Frank Brazier reported a pair with young in Boggy Creek Valley as recently as July, 1960, and a pair was found breeding at Fort San in 1955, but reports of the Yellow-breasted Chat in Saskatchewan are not numerous.

These sightings of the Lazuli Bunting and the Yellow-breasted Chat are interesting because they seem to indicate the northern limit of the ranges of both birds.

\section{RED-HEADED WOODPECKER IN CYPRESS HILLS}

by R. V. Folker, Saskatoon

On June 20, 1963, while travelling through the centre block of the Cypress Hills, Saskatchewan, we noted an adult Red-headed Woodpecker (Melanerpes erythrocephalus) as it landed on a fence post ahead of the car. With its striking pattern consisting of a completely red head, black body and wings showing large white patches, the bird was identified almost immediately by Bob Caldwell and myself.

Caldwell and myself, and then $\mathrm{J}$. Nelson and $J$. Donovan, who were following in a second car, were able to approach quite close to this bird and obtained good views of it. The Red-headed Woodpecker is seen sporadically in the Cypress Hills region and Godfrey (1950, Birds of the Cypress Hills and Flotten Lake Regions, Sask., Nat. Mus. Canada, Bull. No. 120) lists several sight records for it as well as evidence that it may nest in this area. 